\title{
ANALISIS KELAYAKAN FINANSIAL VERSI SYARIAH PADA PEMBIAYAAN INVESTASI PERKEBUNAN KELAPA SAWIT PT.X
}

\author{
Darkiman Ruminta*, Edmon Daris** dan Acep R. Jayaprawira**
}

\begin{abstract}
Tujuan dari penelitian ini adalah; 1) Menganalisis kelayakan finansial versi syariah pada pembiayaan perkebunan kelapa sawit yang diajukan oleh PT.X kepada bank syariah, 2) Menganalisis perubahan harga input dan output dalam menilai kelayakan finansial versi syariah pada pembiayaan investasi perkebunan kelapa sawit yang diajukan oleh PT.X, dan 3) Menganalisis persamaan dan perbedaan antara perhitungan kelayakan pembiayaan versi syariah dengan versi konvensional dalam menganalisis kelayakan finansial proposal pembiayaan perkebunan kelapa sawit. Pendekatan penelitian ini menggunakan metode deskriptif dalam bentuk studi kasus dengan obyek penelitian proposal pembiayaan proyek investasi perkebunan kelapa sawit yang diajukan PT. X. Data penelitian ini mencakup data kuantitatif dan kualitatif. Jenis dan teknik pengumpulan data penelitian mencakup data primer dan data sekunder. Data primer diperoleh melalui wawancara langsung secara intensif dan mendalam dengan berbagai narasumber di kantor Bank Syariah Mandiri yang berkompeten dalam menangani pembiayaan perkebunan kelapa sawit yang diajukan. Sedangkan data sekunder berupa data pendukung diperoleh studi pustaka, hasil penelitian sebelumnya, website Bank Indonesia, website Kementerian Pertanian Indonesia, website Badan Pusat Statistik (BPS), dan instansi terkait lainnya. Hasil analisis kelayakan finansial versi syariah pada proyek investasi perkebunan kelapa sawit PT.X adalah layak untuk dibiayai oleh bank. Berdasarkan hasil perhitungan analisa kelayakan finansial baik versi konvensional maupun versi syariah, dapat disimpulkan bahwa proyek investasi perkebunan kelapa sawit PT.X seluas 2.000 Ha adalah layak untuk dibiayai oleh pihak bank. Penelitian ini hanya melakukan analisa yang ditekankan pada kelayakan aspek finansial, sedangkan pada aspek non finansial diasumsikan layak. Sehingga perlu dilakukan analisa lanjutan semua aspek yang tidak dianalisa mendalam.
\end{abstract}

Kata kunci : kelayakan, keuangan, syariah. 


\begin{abstract}
The purpose of this study is; 1) Analyze the financial feasibility of the version of sharia on the financing of oil palm plantations posed by PT.X to Islamic banks, 2) to analyze changes in input and output prices in assessing the financial viability version of sharia on the financing of oil palm plantation investment proposed by PT.X, and 3) to analyze the similarities and differences between the version of sharia financing feasibility calculations with the conventional version in analyzing the financial feasibility of the financing proposal oil palm plantations. This research approach uses descriptive method in the form of case studies with the object of research proposals financing investment projects proposed oil palm plantation PT. X. This research data includes quantitative and qualitative data. The type of research and data collection techniques include primary data and secondary data. The primary data obtained through direct interviews intensive and in-depth with the various speakers at the offices of Bank Syariah Mandiri competent in dealing with financing the proposed oil palm plantations. While the secondary data obtained supporting literature, results of previous studies, the website of Bank Indonesia, Indonesian Agriculture Ministry's website, the website of the Central Statistics Agency (BPS), and other relevant agencies. The results of a financial analysis on a version of sharia investment projects PT.X oil palm plantations is eligible to be financed by the bank. Based on the calculation of financial feasibility analysis of both versions of conventional and sharia version, it can be concluded that the investment project PT.X oil palm plantation area of 2,000 hectares is eligible to be financed by the bank. This study only analyzes the emphasis on the financial aspects of feasibility, while the non-financial aspects assumed feasible. So that needs to be done further analysis of all aspects that were not analyzed in depth.
\end{abstract}

Keywords : feasibility, financial, sharia,

\section{PENDAHULUAN}

Sampai saat ini penilaian kelayakan investasi suatu proyek umumnya selalu dititikberatkan pada aspek bunga (interest) sebagai ukuran terhadap keuntungan yang akan diterima oleh investor. Tetapi bagi bank syariah, penilaian kelayakan finansial suatu proyek investasi seharusnya menggunakan pola syariah yang bebas aspek bunga. Dengan menggunakan perhitungan analisis kelayakan finansial pola syariah seharusnya lebih memudahkan, menguntungkan dan memberi manfaat, tidak saja bagi bank syariah selaku pemberi pembiayaan tetapi juga bagi pihak pengusaha selaku penerima pembiayaan. Karena bank syariah dibangun berlandaskan pada beberapa faktor; 1) bank syariah lebih dekat dengan sektor riil karena produk yang ditawarkan, khususnya 
pembiayaan menggunakan underlying transaksi di sektor riil, 2) tidak terdapat produk-produk yang bersifat spekulatif (gharar), 3) menggunakan sistem bagi hasil (profit-loss sharing) yang memberikan manfaat lebih adil bagi semua pihak.

Berkaitan dengan pendanaan investasi agribisnis kelapa sawit oleh bank syariah, ada fenomena yang menarik untuk dikaji lebih jauh. Pertama, Islam mendorong seluruh masyarakat untuk melakukan investasi yang halal dan melarang membungakan uang. Kedua, metode untuk menilai kelayakan investasi kelapa sawit secara finansial umumnya masih menggunakan perhitungan tingkat bunga (interest), sementara dalam operasional bank syariah tidak menggunakan aspek bunga (interest). Berdasarkan permasalahan, maka penelitian tentang "Analisis Kelayakan Finansial Versi Syariah pada Pembiayaan Perkebunan Kelapa Sawit“" perlu dilakukan.

Tujuan dari penelitian ini adalah; 1) Menganalisis kelayakan finansial versi syariah pada pembiayaan perkebunan kelapa sawit yang diajukan oleh PT.X kepada bank syariah, 2) Menganalisis perubahan harga input dan output dalam menilai kelayakan finansial versi syariah pada pembiayaan investasi perkebunan kelapa sawit yang diajukan oleh PT.X, dan 3) Menganalisis persamaan dan perbedaan antara perhitungan kelayakan pembiayaan versi syariah dengan versi konvensional dalam menganalisis kelayakan finansial proposal pembiayaan perkebunan kelapa sawit.

\section{METODE PENELITIAN}

Pendekatan penelitian ini menggunakan metode deskriptif dalam bentuk studi kasus dengan obyek penelitian proposal pembiayaan proyek investasi perkebunan kelapa sawit yang diajukan PT. X. Data penelitian ini mencakup data kuantitatif dan kualitatif. Jenis dan teknik pengumpulan data penelitian mencakup data primer dan data sekunder. Data primer diperoleh melalui wawancara langsung secara intensif dan mendalam dengan berbagai narasumber di kantor Bank Syariah Mandiri yang berkompeten dalam menangani pembiayaan perkebunan kelapa sawit yang diajukan oleh PT.X. Sedangkan data sekunder berupa data pendukung diperoleh melalui studi pustaka, hasil-hasil penelitian sebelumnya, website Bank Indonesia, website Kementerian Pertanian Indonesia, website Badan Pusat Statistik (BPS), dan instansi terkait lainnya.

Untuk keperluan analisis kelayakan pembiayaan proyek investasi perkebunan kelapa sawit yang diajukan oleh PT. X digunakan analisis kelayakan investasi versi syariah sebagai berikut :

1. Analisis Break Event Point (BEP)

$$
\mathrm{BEP}=\mathrm{TC}=\mathrm{TR}
$$

2. Analisis Benefit Cost Ratio (B/C Ratio)

Adapun rumus $\mathrm{B} / \mathrm{C}$ ratio adalah :

$$
\text { Net } B / C \text { Ratio }=\frac{\sum_{t=1}^{n} \frac{B_{t}-C_{t}}{(1+i)^{t}}}{\sum_{t=1}^{n} \frac{C_{t}-B_{t}}{(1+i)^{t}}} \mid
$$


Keterangan :

$\mathrm{Bt}=$ penerimaan kotor pada tahun ke$\mathrm{t}$

$\mathrm{Ct}=$ biaya kotor pada tahun ke- $\mathrm{t}$

$\mathrm{n} \quad=$ umur ekonomi proyek

$\mathrm{i} \quad=$ tingkat suku bunga yang berlaku

3. Analisis Payback periode (PP)

Adapun rumus Payback periode (PP) adalah :

$P P=\frac{\text { Investasi }}{\text { Laba tunai rata-rata per tahun }}$ atau

$P P=T_{p}-1+\frac{\sum_{i=1}^{n} I-\sum_{i=1}^{n} B_{i c p}-1}{B_{p}}$

Keterangan :

Tp-1 = tahun sebelum terdapat PP

Ii = jumlah investasi yang telah di discount

Bicp-1= jumlah pendapatan yang telah di discount sebelum PP

$\mathrm{Bp} \quad=$ jumlah pendapatan pada $\mathrm{PP}$

4. Analisis Net Present Value (NPV)

$$
N P V=\sum_{t=1}^{n} \frac{B_{t}-C_{t}}{(1+i)^{t}}
$$

Keterangan :

$\mathrm{Bt}=$ penerimaan proyek pada tahun ke- $\mathrm{t}$

$\mathrm{Ct}$ = biaya proyek pada tahun ke- $\mathrm{t}$

$\mathrm{n} \quad=$ umur ekonomi proyek

$\mathrm{i}$ = tingkat suku bunga yang berlaku
5. Analisis Internal Rate of Return (IRR)

$$
I R R=i_{1}+\frac{N P V_{1}^{-}}{N P V_{1}-N P V_{2}}\left(i_{2}-i_{1}\right)
$$

Keterangan :

NPV1 = NPV yang bernilai positif

NPV2 = NPV yang bernilai negatif

I1 = tingkat suku bunga saat

NPV bernilai positif

$\mathrm{I} 2$ = tingkat suku bunga saat NPV

bernilai negative

Atau dengan rumus :

$$
I R R=\sum_{t=0}^{n} C F_{t}\left(P V I F_{I R R}\right)
$$

6. Analisis Investible Surplus Method (ISM)

$$
\begin{aligned}
& I S_{n}=\sum_{t=1}^{n}\left(B_{t}-C_{t}\right)(n-t) \\
& \text { Untuk seluruhnya }\left(B_{t}-C_{t}\right)>0
\end{aligned}
$$

Keterangan :
Isn $=$ Surplus $\quad$ yang dapat diinvestasikan setelah $\mathrm{n}$ tahun

$\mathrm{Bt}=$ Keuntungan yang dapat diterima, seperti pendapatan kas

$\mathrm{Ct}$ = Biaya yang terjadi, seperti pengeluaran kas

$\mathrm{n} \quad=$ Umur dari proyek

$\mathrm{t}=$ Periode waktu 


\section{HASIL DAN PEMBAHASAN}

Untuk menganalisis kelayakan pembiayaan investasi perkebunan kelapa sawit PT.X, peneliti menggunakan perhitungan versi syariah dengan tidak menggunakan instrumen tingkat suku bunga bank sebagai indikator perhitungan melainkan dengan menggunakan nisbah bagi hasil (profit loss sharing)) sebagai indikator perhitungan. Secara umum prinsip bagi hasil dalam perbankan syariah dapat dilakukan dalam 4 (empat) akad utama; musyarakah, mudharabah,, muzara'ah dan musaqah. Namun demikian, prinsip bagi hasil yang paling banyak dipakai di perbankan syariah adalah musyarakah dan mudharabah, sehingga dalam penelitian ini peneliti menggunakan skim pembiayaan musyarakah. Sedangkan rumus perhitungan matematikanya masih menggunakan rumus analisis kelayakan finansial yang umum dipakai yakni; NPV, IRR, payback periode, Net B/C Ratio dan Investible Surplus Methode (ISM).

Alasan menggunakan prinsip bagi hasil dengan skim musyarakah karena transaksi pada musyarakah dilandasi adanya keinginan para pihak (dalam hal ini PT.X dan BSM) yang bekerja sama untuk meningkatkan nilai aset yang mereka miliki secara bersama-sama. Semua bentuk usaha yang melibatkan dua pihak atau lebih dimana mereka secara bersama-sama memadukan seluruh bentuk sumber daya baik yang berwujud maupun tidak.

Tabel 1. Kebutuhan Biaya Investasi Kebun Kelapa Sawit

\begin{tabular}{|c|c|c|c|c|c|c|}
\hline & \multirow[b]{2}{*}{ URAIAN } & \multirow{2}{*}{$\begin{array}{c}\text { LUAS } \\
\text { (Ha) }\end{array}$} & \multicolumn{2}{|c|}{ BIAYA VERSI PT.X } & \multicolumn{2}{|c|}{ BIAYA VERSI Peneliti } \\
\hline & & & Total & $\begin{array}{c}\text { Rata-rata } \\
/ \text { Ha }\end{array}$ & Total & $\begin{array}{c}\text { Rata-rata } \\
/ \text { Ha }\end{array}$ \\
\hline I. & Plantation & & & & & \\
\hline 1. & Pembibitan & 2,000 & 7.443 .960 .000 & 3.721 .980 & 7.262 .400 .000 & 3.631 .200 \\
\hline 2. & Land Clearing & 2,000 & 16.096 .600 .000 & 8.048 .300 & 15.704 .000 .000 & 7.852 .000 \\
\hline 3. & Penanaman + LCC & 2,000 & 11.793 .650 .000 & 5.896 .825 & 11.506 .000 .000 & 5.753 .000 \\
\hline 4. & Pemiliharaan TBM-1 & 2,000 & $12.228 .250,000$ & 6.114 .125 & 11.930 .000 .000 & 5.965 .000 \\
\hline 5. & Pemeliharaan TBM-2 & 2,000 & 13.506 .638 .000 & 6.753 .319 & 13.177.500.000 & 6.588 .750 \\
\hline 6. & Pemeliharaan TBM-3 & 2,000 & 14.182 .284 .000 & 7.091 .142 & 14.828 .625 .000 & 7.414 .313 \\
\hline II. & Non Plantation & & & & & \\
\hline 1. & Infrastruktur kebun & 2.000 & 9.249 .061 .900 & 4.624 .531 & 9.960 .288 .462 & 4.980 .144 \\
\hline III. & $\begin{array}{l}\text { Pre Operation } \\
\text { Cost }\end{array}$ & & & & & \\
\hline 1. & Pre Operation Cost+legal & 2.000 & 5.500 .000 .000 & 2.750 .000 & 6.500 .000 .000 & 3.250 .000 \\
\hline$I V$. & Manajemen Fee & & & & & \\
\hline 1. & Manajemen fee & 2.000 & 4.500 .037 .000 & 2.250 .018 & 4.543 .440 .673 & 2.271 .720 \\
\hline TOT & L INVESTASI (diluar IDC) & & 94.500 .480 .900 & 47.250 .241 & 95.412.254.135 & 47.706.127 \\
\hline$V$ & $\begin{array}{l}\text { Interest During } \\
\text { Construction (IDC) }\end{array}$ & 2.000 & 35.211 .065 .000 & 17.606 .000 & 40.970 .111 .834 & 20.485 .056 \\
\hline $\begin{array}{l}\text { TOT } \\
\text { IDC) }\end{array}$ & L INVESTASI (termasuk & & 129.712.000.000 & & 136.382.365.968 & \\
\hline
\end{tabular}

Sumber : Data diolah 
Pada perbankan syariah, skim musyarakah biasanya diaplikasikan untuk pembiayaan proyek dimana pihak nasabah dan pihak bank bersama-sama menyediakan dana untuk membiayai proyek. Setelah proyek selesai, nasabah mengembalikan dana tersebut bersama bagi hasil yang telah disepakati untuk pihak bank. Berikut disajikan tabel kebutuhan biaya investasi Kebun Kelapa Sawit.

Berdasarkan review terhadap proposal pembiayaan yang diajukan oleh

Selanjutnya untuk menilai kelayakan pembiayaan investasi yang diajukan oleh PT.X akan digunakan asumsi-asumsi pokok dalam rangka penyusunan proyeksi keuangan, yakni; asumsi teknis dan asumsi proyeksi finansial dengan berdasar pada pengalaman BSM dalam membiayai proyek perkebunan kelapa sawit. Asumsi yang digunakan oleh peneliti adalah sebagai berikut :

a. Asumsi produktivitas lahan dan rendemen hasil mengacu kepada pengalaman hasil perkebunan sebelumnya yang ada di wilayah Kalimantan Tengah dan juga mengacu pada standar yang dibuat oleh Pusat Penelitian Kelapa Sawit (PPKS) Marihat. Produktivitas tanaman kelapa sawit juga ditentukan oleh profil produksi yang mengikuti umur tanaman, sehingga asumsi produktivitas lahan yang digunakan
PT.X kepada Bank Syariah Mandiri diketahui bahwa biaya investasi yang dibutuhkan untuk pembangunan kebun kelapa sawit seluas $2.000 \mathrm{Ha}$ adalah sebesar Rp 129.712.000.000,-. Dari data terlihat bahwa ada perbedaan antara total biaya investasi versi PT.X dengan hasil estimasi total biaya investasi versi peneliti berdasarkan informasi dari pihak BSM, hal ini terjadi karena pihak peneliti memperhitungkan kenaikan inflasi 5\% per tahun terhadap semua komponen biaya sehingga hasil estimasi biaya investasi versi peneliti lebih besar dibanding versi PT.X yaitu sebesar Rp 136.382.365.968,- atau ada selisih sebesar Rp 6.670.365.960,-.

adalah seperti yang disajikan dalam tabel di bawah ini.

b. Jadwal pembangunan proyek kebun kelapa sawit PT.X seluas 2.000 ha direncanakan dilaksanakan secara sekaligus 1 tahun yaitu tahun 2012/2013. Sejak pembukaan lahan hingga Tanaman Menghasilkan (TM) membutuhkan waktu lebih kurang 3 - 4 tahun. Pada kondisi tanah mineral, biasanya hanya membutuhkan waktu 4 tahun untuk mencapai Tanaman Menghasilkan (TM).

c. Siklus produksi tanaman kelapa sawit; TM 1-2 tanaman baru belajar untuk berbuah sehingga produktivitasnya masih rendah maka kebutuhan pupuk juga belum besar, TM 3-5 tanaman berpotensi untuk menghasilkan buah lebih banyak namun belum terlalu banyak sehingga dibutuhkan pemupukan dalam dosis yang lebih 
tinggi guna menstimulus produktivitas buah sesuai dengan kemampuannya. Pada TM 6-13 tanaman mempunyai potensi menghasilkan buah yang maksimal sehingga dibutuhkan pemupukan dalam dosis lebih banyak. Pada TM14-22 kemampuan tanaman untuk menghasilkan buah sudah menunjukkan trend penurunan dan pemupukan ditujukan untuk perawatan tanaman sehingga kebutuhan pupuk pada periode ini paling rendah.

Sedangkan untuk asumsi finansial dan batasan yang digunakan dalam pembahasan investasi PT.X versi peneliti yang berdasarkan masukan dari pihak bank adalah sebagai berikut :

a. Angsuran disesuaikan dengan kemampuan pihak mitra (dalam hal ini PT.X) sehingga tidak ada istilah masa tenggang (grace period), kalaupun ada maka istilahnya masa pembayaran manual dalam hal ini akan disesuaikan dengan masa proyek mulai menghasilkan yaitu sekitar 4 tahun sejak akad perjanjian pembiayaan.
Ketentuan penyediaan dana sendiri (self financing) dalam penelitian ini sesuai dengan ketentuan BSM, dimana pengenaan dana sendiri (self financing) yang harus dipenuhi oleh PT.X minimal sebesar 30\% dari total kebutuhan proyek atau maksimum porsi pembiayaan adalah 70\%. Dalam penelitian ini dilakukan perhitungan langsung dengan menggunakan porsi pembiayaan tertinggi yang diperkenankan dalam peraturan pembiayaan BSM yakni 70:30. Selanjutnya dalam skim pembiayaan musyarakah, pembagian nisbah bagi hasil porsinya adalah $70 \%$ untuk pihak PT.X dan $30 \%$ untuk pihak bank. Tabel 2 menyajikan asumsi produktifitas lahan, dan rendemen CPO dan kernel.

Asumsi biaya berkaitan dengan pemeliharaan dan perawatan kebun kelapa sawit adalah sebagai berikut:

Biaya pemeliharaan Tanaman Menghasilkan (TM) mengacu kepada standar pemeliharaan TM yang umum dipakai oleh usaha perkebunan kelapa sawit. Acuan utamanya adalah standar yang dibuat oleh

Tabel 2. Asumsi Produktivitas Lahan, Rendemen CPO dan Kernel

\begin{tabular}{|c|c|c|c|c|c|}
\hline \multirow{2}{*}{$\begin{array}{c}\text { Umur } \\
\text { Tanaman } \\
\text { (tahun) }\end{array}$} & \multirow{2}{*}{$\begin{array}{c}\text { Produkstivitas } \\
\text { LahanVersi Hasil } \\
\text { Perkebunan sebelumnya } \\
\text { dan PPKS (ton } \\
\text { TBS/ha/tahun) }\end{array}$} & \multirow[b]{2}{*}{$\begin{array}{c}\text { Penilaian } \\
\text { Peneliti }\end{array}$} & \multirow{2}{*}{$\begin{array}{c}\text { Produkstivitas } \\
\begin{array}{c}\text { Lahan Penilaian } \\
\text { Bank (ton } \\
\text { TBS/ha/tahun) }\end{array}\end{array}$} & \multicolumn{2}{|c|}{ Rendemen } \\
\hline & & & & $\begin{array}{c}\text { CPO } \\
(\%)\end{array}$ & $\begin{array}{c}\text { Kernel } \\
(\%)\end{array}$ \\
\hline 4 & 7,00 & 90 & 6,3 & 19,00 & 4,50 \\
\hline 5 & 14,00 & 95 & 13,3 & 19,00 & 4,80 \\
\hline 6 & 18,00 & 95 & 17,1 & 20,00 & 5,10 \\
\hline 7 & 21,00 & 95 & 20,0 & 21,00 & 5,40 \\
\hline 8 & 24,50 & 95 & 23,3 & 21,00 & 5,40 \\
\hline
\end{tabular}




\begin{tabular}{rrrrrr}
9 & 26,50 & 95 & 25,2 & 22,00 & 5,40 \\
10 & 27,00 & 95 & 25,7 & 22,00 & 5,40 \\
11 & 27,00 & 95 & 25,7 & 23,00 & 5,40 \\
12 & 27,00 & 95 & 25,7 & 23,00 & 5,40 \\
13 & 27,00 & 95 & 25,7 & 24,00 & 5,40 \\
14 & 26,50 & 95 & 25,2 & 24,00 & 5,40 \\
15 & 25,50 & 95 & 24,2 & 24,00 & 5,40 \\
16 & 25,00 & 95 & 23,8 & 24,00 & 5,40 \\
17 & 24,00 & 95 & 22,8 & 24,00 & 5,40 \\
18 & 23,00 & 95 & 21,9 & 24,00 & 5,40 \\
19 & 22,50 & 95 & 21,4 & 24,00 & 5,40 \\
20 & 21,00 & 95 & 20,0 & 24,00 & 5,40 \\
21 & 20,50 & 95 & 19,5 & 24,00 & 5,40 \\
22 & 19,50 & 95 & 18,5 & 24,00 & 5,40 \\
23 & 18,50 & 95 & 17,6 & 24,00 & 5,40 \\
24 & 17,50 & 95 & 16,6 & 24,00 & 5,40 \\
25 & 17,00 & 95 & 16,2 & 24,00 & 5,40 \\
26 & 16,50 & 95 & 15,7 & 24,00 & 5,40 \\
27 & 16,50 & 95 & 15,7 & 24,00 & 5,40 \\
28 & 15,50 & 95 & 14,7 & 24,00 & 5,40 \\
\hline
\end{tabular}

Sumber : Data diolah

Pusat Penelitian Kelapa Sawit (PPKS) Marihat dan realisasi biaya pemeliharaan TM juga berdasarkan pengalaman biaya pemeliharaan dari sejumlah mitra BSM sebelumnya, dimana biaya pemeliharaan TM per hektar adalah sebesar Rp 5.700.000,. Selanjutnya untuk setiap tahunnya dinaikkan biayanya sebesar 5\% dengan memperhitungkan kenaikan inflasi $5 \%$ per tahun.

Penentuan harga Tandan Buah Segar (TBS) ditetapkan berdasarkan atas harga yang berlaku. Idealnya penentuan harga TBS adalah sesuai dengan Peraturan Menteri Pertanian Nomor : 395/Kpts/OT.140/11/2005 tentang Pedoman Penetapan Harga Pembelian Tandan Buah Segar (TBS) Kelapa Sawit
Produksi Pekebun dengan rumus sebagai berikut :

$$
P_{\text {TBS }}=K\left(H_{m s} \times R_{m s}+H_{\text {is }} \times R_{\text {is }}\right)
$$

3. Biaya panen dan angkutan TBS per $\mathrm{kg}$ ditetapkan sebesar Rp 150.000,- per ton yang diasumsikan naik setiap tahunnya sebesar 5\% per tahun.

4. Biaya umum dan administrasi, dalam komponen biaya ini diidentifikasi berdasarkan dari acuan biaya realisasi biaya umum dan administrasi beberapa mitra perusahaan kelapa sawit yang dibiayai oleh BSM. Seluruh komponen biaya-biaya ini diasumsikan naik setiap tahunnya sebesar 5\% per tahun.

5. Biaya penyusutan dan amortisasi dihitung berdasarkan persentase dari nilai perolehan dana di saat aktiva 
tersebut telah habis, nilai bukunya dilakukan pembelian baru atas aktiva tersebut dengan nilai perolehan diasumsikan sama dengan periode pembelian sebelumnya.

\section{Penentuan Nisbah Bagi Hasil Penjualan (Revenue)}

Berdasarkan hasil perhitungan arus kas, penerimaan, pengeluaran dan lainnya maka selanjutnya dilakukan analisis terhadap kelayakan finansial proyek investasi perkebunan kelapa sawit PT.X dengan menggunakan rumus yang biasa digunakan antara lain; break even, $N P V$, $I R R$, Payback period, $\mathrm{B} / \mathrm{C}$ ratio, dan ISM. Dalam perhitungan ini, peneliti menggunakan indikator perhitungan antara lain :

1. Untuk versi syariah dengan skim musyarakah

2. Menggunakan nisbah bagi hasil sebagai pengganti tingkat suku bunga bank. Dalam perhitungan ini menggunakan bagi hasil dengan basis penjualan.

3. Nisbah bagi hasil dihitung jika proyek sudah menghasilkan atau sudah ada penjualan sehingga ada penerimaan (revenue).

Komposisi bagi hasil antara pihak PT. $\mathrm{X}$ dengan pihak bank dilakukan uji komposisi angka dengan pilihan :

\begin{tabular}{ccc}
\hline Komposisi & $\begin{array}{l}\text { Bagi hasil } \\
\text { untuk PT. } \\
\text { X (\%) }\end{array}$ & $\begin{array}{l}\text { Bagi hasil } \\
\text { untuk Bank } \\
(\%)\end{array}$ \\
\hline I & 90 & 10 \\
II & 92 & 8 \\
III & 95 & 5 \\
\hline
\end{tabular}

Dari ketiga komposisi bagi hasil, yang lebih mendekati unsur keadilan baik untuk pihak PT.X maupun pihak bank adalah komposisi bagi hasil 92\% : 8\% dengan total hasil yang diperoleh pihak bank sebesar Rp 40.620.930.557,-. Angka ini mendekati alokasi biaya (pokok+bagi hasil) dalam proposal PT.X yang diajukan kepada BSM yaitu sebesar Rp 35.211.065.000,-. Salah satu kelebihan dari bagi hasil ini adalah masing-masing pihak sudah bisa melakukan bagi hasil pada tahun ke-4 setelah tanam dan hal ini akan memberi sedikit keuntungan bagi pihak bank karena sudah ada penerimaan bagi hasil. Secara ringkas hasil perhitungan penilaian kelayakan finansial versi syariah proyek investasi perkebunan kelapa sawit PT. X disajikan pada tabel 3.

Berdasarkan hasil perhitungan analisa kelayakan finansial versi syariah yang menggunakan nisbah bagi hasil penjualan (revenue), dapat disimpulkan bahwa proyek investasi perkebunan kelapa sawit PT.X seluas 2.000 Ha adalah layak untuk dibiayai oleh pihak bank.

\section{Penentuan Nisbah Bagi Hasil Keuntungan (Profit Surplus)}

Berdasarkan hasil perhitungan arus kas, penerimaan, pengeluaran dan lainnya maka selanjutnya dilakukan analisis terhadap kelayakan finansial proyek 
investasi perkebunan kelapa sawit PT.X dengan menggunakan rumus yang biasa digunakan antara lain; break even, NPV, $I R R$, Payback period, $\mathrm{B} / \mathrm{C}$ ratio, dan ISM. Dalam perhitungan ini, peneliti menggunakan indikator perhitungan antara lain :

1. Untuk versi syariah dengan skim musyarakah

2. Menggunakan nisbah bagi hasil sebagai pengganti tingkat suku bunga bank. Dalam perhitungan ini menggunakan bagi hasil dengan basis keuntungan atau laba bersih (profit surplus) dari net income.

3. Nisbah bagi hasil dihitung jika proyek sudah menghasilkan keuntungan atau profit surplus (net income).

4. Komposisi bagi hasil antara pihak PT. $\mathrm{X}$ dengan pihak bank dilakukan uji komposisi angka dengan pilihan :

\begin{tabular}{ccc}
\hline Komposisi & $\begin{array}{c}\text { Bagi hasil } \\
\text { untuk PT.X }\end{array}$ & $\begin{array}{c}\text { Bagi hasil } \\
\text { untuk Bank }\end{array}$ \\
\hline I & $65 \%$ & $35 \%$ \\
II & $70 \%$ & $30 \%$ \\
III & $75 \%$ & $25 \%$ \\
\hline
\end{tabular}

Perbedaan antara bagi hasil berbasis penjualan dengan bagi hasil berbasis laba bersih adalah terletak pada dasar perhitungan bagi hasilnya, yakni :

1. Untuk bagi hasil berbasis penjualan menggunakan perhitungan dari nilai hasil penjualan (revenue) sebagai dasar perhitungan. Berapa pun nilai penjualannya maka masing-masing pihak sudah boleh melakukan perhitungan bagi hasil.

2. Sedangkan untuk bagi hasil berbasis laba menggunakan perhitungan dari nilai hasil laba bersih (net income) sebagai dasar perhitungan. Berapa pun nilai laba bersih yang dihasilkan, maka masing-masing pihak sudah boleh melakukan perhitungan bagi hasil sesuai akad kesepakatan bersama.

Secara ringkas hasil perhitungan penilaian kelayakan finansial versi syariah proyek investasi perkebunan kelapa sawit PT. X menggunakan nisbah bagi hasil berbasis nilai laba bersih disajikan pada tabe; 4 .

Tabel 3. Kelayakan Proyek PT. X Versi Syariah Bagi Hasil Berbasis Penjualan

\begin{tabular}{|c|c|c|c|c|c|c|}
\hline \multirow{3}{*}{ Uraian } & \multicolumn{6}{|c|}{ Versi Syariah } \\
\hline & \multirow{2}{*}{\multicolumn{2}{|c|}{$\begin{array}{l}\text { Bagi hasil penjualan } \\
\text { Nisbah }(\%)=90: 10\end{array}$}} & \multirow{2}{*}{\multicolumn{2}{|c|}{$\begin{array}{l}\text { Bagi hasil penjualan } \\
\text { Nisbah }(\%)=92: 8 \\
\end{array}$}} & \multirow{2}{*}{\multicolumn{2}{|c|}{$\begin{array}{l}\text { Bagi hasil penjualan } \\
\text { Nisbah }(\%)=95: 5 \\
\end{array}$}} \\
\hline & & & & & & \\
\hline Net Present Value (NPV) & $\mathbf{R p}$ & 174.107.446.306 & $\mathbf{R p}$ & 172.235 .672 .879 & $\mathbf{R p}$ & 170.712.419.150 \\
\hline Payback period - tahun & & 7,21 & & 7,22 & & 7,25 \\
\hline B/C Ratio & & 2,55 & & 2,53 & & 2,52 \\
\hline Break even (BE) & & tahun ke 6 & & tahun ke 6 & & tahun ke 5 \\
\hline $\begin{array}{l}\text { Investible Surplus Methode } \\
\text { (ISM) }\end{array}$ & $\mathbf{R p}$ & $\begin{array}{r}118.555 .965 .131 \\
\text { tahun ke } 10\end{array}$ & $\mathbf{R p}$ & $\begin{array}{r}124.696 .248 .114 \\
\text { tahun ke } 10\end{array}$ & $\mathbf{R p}$ & $\begin{array}{r}135.850 .037 .511 \\
\text { tahun ke } 10\end{array}$ \\
\hline
\end{tabular}




\begin{tabular}{|c|c|c|c|c|c|c|}
\hline$(I R R)$ & & $20,58 \%$ & & $20,49 \%$ & & $20,41 \%$ \\
\hline $\begin{array}{l}\text { Hasil yang didapat oleh } \\
\text { bank }\end{array}$ & $\mathbf{R p}$ & 50.776.163.197 & $\mathbf{R p}$ & 40.620.930.557 & Rp & 25.388.081.598 \\
\hline
\end{tabular}

Tabel 4. Kelayakan Proyek PT. X Versi Syariah Bagi Hasil Berbasis Laba

\begin{tabular}{|c|c|c|c|c|c|c|}
\hline \multirow{3}{*}{ Uraian } & \multicolumn{6}{|c|}{ Versi Syariah } \\
\hline & \multicolumn{2}{|c|}{ Bagi hasil laba } & \multicolumn{2}{|c|}{ Bagi hasil laba } & \multicolumn{2}{|c|}{ Bagi hasil laba } \\
\hline & Nisb & $(\%)=65: 35$ & Nish & $h(\%)=70: 30$ & Nisb & $(\%)=75: 25$ \\
\hline Net Present Value (NPV) & $\mathbf{R p}$ & 173.597.552.152 & $\mathbf{R p}$ & 172.802.221.667 & $\mathbf{R p}$ & 172.006 .891 .182 \\
\hline Payback period (PP) - tahun & & 7,23 & & 7,24 & & 7,25 \\
\hline B/C Ratio & & 2,54 & & 2,54 & & 2,53 \\
\hline Break even (BE) & & tahun ke 5 & & tahun ke 5 & & tahun ke 5 \\
\hline $\begin{array}{l}\text { Investible Surplus Methode } \\
\text { (ISM) }\end{array}$ & $\mathbf{R p}$ & $\begin{array}{r}154.198 .008 .423 \\
\text { tahun ke } 10\end{array}$ & $\mathbf{R p}$ & $\begin{array}{r}\text { 154.198.008.423 } \\
\text { tahun ke } 10\end{array}$ & $\mathbf{R p}$ & $\begin{array}{r}154.198 .008 .423 \\
\text { tahun ke } 10\end{array}$ \\
\hline $\begin{array}{l}\text { Internal Rate of Return } \\
\text { (IRR) }\end{array}$ & & $20,55 \%$ & & $20,51 \%$ & & $20,47 \%$ \\
\hline $\begin{array}{l}\text { Hasil yang didapat oleh } \\
\text { bank }\end{array}$ & $\mathbf{R p}$ & 53.969.302.948 & $\mathbf{R p}$ & 46.259.402.527 & $\mathbf{R p}$ & 38.549.502.106 \\
\hline
\end{tabular}

Dari ketiga komposisi bagi hasil di atas, yang lebih mendekati unsur keadilan baik untuk pihak PT.X maupun pihak bank adalah komposisi bagi hasil 70\% : 30\% dengan total hasil yang diperoleh pihak bank sebesar Rp 46.259.402.527,-. Angka ini ini memang lebih besar dari alokasi biaya (pokok+bagi hasil) dalam proposal PT.X yang diajukan kepada BSM yaitu sebesar Rp 35.211.065.000,-, tetapi dari sisi masa pembayaran yang baru dilakukan pada tahun ke-5, maka dinilai cukup adil karena menghargai usaha pihak bank selaku pemberi dana terbesar yang sabar menunggu bagi hasil selama 5 tahun. Dari proyeksi laporan laba rugi dapat dilihat bahwa salah satu kelemahan dari bagi hasil ini adalah masing-masing pihak baru bisa melakukan bagi hasil pada tahun ke-5 setelah tanam dan hal ini kemungkinan akan memberatkan salah satu pihak yaitu pihak bank karena lama tidak ada penerimaan.

Berdasarkan hasil perhitungan analisa kelayakan finansial versi syariah yang menggunakan nisbah bagi hasil dari laba bersih/profit surplus (net income), dapat disimpulkan bahwa proyek investasi perkebunan kelapa sawit PT.X seluas 2.000 Ha adalah layak untuk dibiayai oleh pihak bank.

Dalam penelitian ini, peneliti mengidentifikasi 2 (dua) variabel yang diduga berpengaruh secara sensitif terhadap keuntungan proyek, yaitu : biaya produksi (harga input) dan harga jual produk (harga output). Kedua variabel tersebut selanjutnya diuji masing-masing secara independen terpisah dengan asumsi cateris paribus (kondisi yang lain tetap) dan juga variabel tersebut diuji secara simultan. Percobaan angka yang dipakai dalam 
simulasi harga jual produk (harga output) adalah berdasarkan data yang diperoleh selama 5 tahun terakhir dimana trend kenaikan harga output sebesar 5\%. Sedangkan angka untuk biaya produksi (biaya input) berdasarkan kenaikan harga yang mungkin terjadi karena faktor naiknya harga barang-barang sarana produksi, biaya upah tenaga kerja (UMP) dan faktor angka inflasi.

Tabel 5. . Hasil Analisis Sensitivitas

\begin{tabular}{|c|c|c|c|c|c|}
\hline \multirow{3}{*}{ Uraian } & \multicolumn{5}{|c|}{ Analisis Sensitivitas } \\
\hline & & Harga input & Harga ouput & & Simultan \\
\hline & & naik $5 \%$ & naik 5\% & & input-output \\
\hline Net Present Value (NPV) & $\mathrm{Rp}$ & 160.326 .793 .535 & Rp 186.318.732.207 & $\mathrm{Rp}$ & 179.952.065.099 \\
\hline Payback period (PP) & & 7,32 & 7,09 & & 7,16 \\
\hline $\begin{array}{l}\text { B/C Ratio } \\
\text { Internal Rate of Return }\end{array}$ & & 2,43 & 2,66 & & 2,60 \\
\hline (IRR) & & $19,95 \%$ & $21,05 \%$ & & $20,77 \%$ \\
\hline
\end{tabular}

Sumber : Data diolah

Perkembangan angka inflasi propinsi Kalimantan Tengah Tahun 2009-2012 adalah sebesar $5,17 \%$ atau dibulatkan menjadi 5\%.

Berdasarkan perhitungan uji simulasi perubahan 1 variabel dengan asumsi variabel lain tetap atau cateris paribus,

Berdasarkan perhitungan uji simulasi perubahan 1 variabel dengan asumsi variabel lain tetap atau cateris paribus, maka hasil analisa sensitivitas menunjukkan bahwa secara keseluruhan proyek investasi masih layak. Begitu juga dengan perhitungan uji simulasi perubahan 2 variabel yang simultan secara bersamasama antara variabel naiknya harga input dengan naiknya harga output, proyek investasi dinilai masih sangat layak. Secara ringkas hasil analisis sensitivitas disajikan pada tabel 5 .

$\begin{array}{clr}\text { Berdasarkan } & \text { hasil analisis } \\ \text { sensitivitas, ternyata } & \text { proyek investasi }\end{array}$ perkebunan kelapa sawit PT. X masih layak untuk didanai oleh bank, karena semua angka hasil analisis di atas syarat nilai minimal ketentuan analisis kelayakan finansial, yaitu; nilai NPV di atas 1 atau nilainya positif, nilai $\mathrm{B} / \mathrm{C}$ ratio juga di atas 1, nilai IRR di atas tingkat suku bunga yang diharapkan dan payback periode lebih rendah dari jangka waktu pembiayaan yang ditentukan. Adapun variabel yang patut diduga akan menjadi variabel yang dominan mempengaruhi sensitivitas keuntungan proyek adalah variabel harga output. Karena variabel ini adalah variabel yang paling sering bergejolak dan pernah mempengaruhi bisnis komoditas kelapa sawit. 
Tabel 6. Perhitungan Versi Konvensional dan Versi Syariah

\begin{tabular}{|c|c|c|c|c|c|c|}
\hline \multirow{3}{*}{ Uraian } & \multirow{2}{*}{\multicolumn{2}{|c|}{$\begin{array}{c}\text { Versi Konvensional } \\
\text { (Fixed) }\end{array}$}} & \multicolumn{4}{|c|}{ Versi Syariah } \\
\hline & & & \multirow{2}{*}{\multicolumn{2}{|c|}{\begin{tabular}{|l} 
Bagi hasil penjualan \\
Nisbah $(\%)=92: 8$
\end{tabular}}} & \multirow{2}{*}{\multicolumn{2}{|c|}{$\begin{array}{c}\text { Bagi hasil laba } \\
\text { Nisbah }(\%)=70: 30\end{array}$}} \\
\hline & & unga $11 \%$ & & & & \\
\hline Net Present Value (NPV) & $\mathbf{R p}$ & 166.693 .460 .644 & Rp & 172.235 .672 .879 & $\mathbf{R p}$ & 172.802 .221 .667 \\
\hline Payback period (PP)-tahun & & 7,25 & & 7,22 & & 7,24 \\
\hline B/C Ratio & & 2,48 & & 2,53 & & 2,54 \\
\hline Break even (BE) & & tahun ke 6 & & tahun ke 6 & & tahun ke 5 \\
\hline $\begin{array}{l}\text { Investible Surplus Methode } \\
\text { (ISM) }\end{array}$ & $\mathbf{R p}$ & $\begin{array}{r}152.142 .821 .653 \\
\text { tahun ke } 10\end{array}$ & $\mathbf{R p}$ & $\begin{array}{r}124.696 .248 .114 \\
\text { tahun ke } 10\end{array}$ & $\mathbf{R p}$ & $\begin{array}{r}154.198 .008 .423 \\
\text { tahun ke } 10\end{array}$ \\
\hline $\begin{array}{l}\text { Internal Rate of Return } \\
\text { (IRR) }\end{array}$ & & $20,24 \%$ & & $20,49 \%$ & & $20,51 \%$ \\
\hline Hasil yang didapat oleh bank & Rp & 62.706 .528 .253 & Rp & 40.620 .930 .557 & $\mathbf{R p}$ & 46.259.402.527 \\
\hline $\begin{array}{l}\text { Mulai pembayaran } \\
\text { angsuran ke bank }\end{array}$ & & ahun ke-2 & & Tahun ke- 4 & & ahun ke- 5 \\
\hline
\end{tabular}

Harga CPO dunia sangat dinamis bisa naik turun mengikuti faktor-faktor; isu dan perekonomian global serta perdagangan internasional yang terkait sisi penawaran dan permintaan minyak sawit dunia. Sehingga harus diantisipasi secara terus menerus, terutama apabila terjadi gejala penurunan harga CPO dunia.

\section{Persamaan dan Perbedaan Perhitungan Kelayakan Finansial}

Persamaan antara perhitungan kelayakan finansial versi konvensional dengan versi syariah terletak pada rumus matematika perhitungannya, yaitu seperti rumus; Net Present Value (NPV), Internal Rate of Return (IRR), Payback Period, dan B/C Ratio.Berdasarkan hasil perhitungan arus kas, penerimaan, pengeluaran dan lainnya maka selanjutnya dilakukan analisis terhadap kelayakan finansial proyek investasi perkebunan kelapa sawit PT.X dengan menggunakan rumus yang biasa digunakan antara lain; break even, NPV, IRR, Payback period, B/C ratio, dan ISM.

Dalam perhitungan ini, peneliti menggunakan indikator perhitungan antara lain :

1. Untuk versi konvensional menggunakan tingkat suku bunga $11 \%$ secara tetap (fixed)

2. Untuk versi syariah dengan skim musyarakah menggunakan nisbah bagi hasil sebagai pengganti bunga bank, yaitu :

a. Bagi hasil berbasis penjualan (revenue), dengan komposisi bagi hasil antara pihak PT.X dengan pihak bank adalah $92 \%: 8 \%$.

b. Bagi hasil berbasis laba bersih (net income) dengan komposisi bagi hasil antara pihak PT.X dengan pihak bank adalah $70 \%: 30 \%$. 
Berdasarkan hasil perhitungan, maka perhitungan versi konvensional yang menggunakan indikator perhitungan tingkat suku bunga $11 \%$ ternyata menghasilkan nilai NPV sebesar Rp 166.693.460.644,-Secara angka nilai NPV yang dihitung menggunakan versi konvensional lebih kecil bila dibandingkan dengan nilai NPV yang dihitung berdasarkan versi syariah, baik dengan menggunakan nisbah bagi hasil berbasis penjualan yaitu NPV sebesar Rp 172.235.672.879,-- maupun nisbah bagi hasil berbasis keuntungan atau laba dengan NPV Rp 172.802.221.667,--. Artinya untuk perhitungan NPV, hasil perhitungan versi syariah yang menggunakan nisbah bagi hasil lebih baik dibandingkan dengan menggunakan tingkat suku bunga $11 \%$ yang bersifat tetap (fixed). Secara umum hasil perhitungan NPV lebih besar dari 0 atau nilainya positif, sehingga disimpulkan investasi ini layak dibiayai oleh bank.

Adapun perbedaan yang sangat signifikan pada perhitungan analisa kelayakan finansial antara versi konvensional dengan versi syariah adalah :

1. Secara angka nilai NPV yang dihitung menggunakan versi konvensional sebesar Rp 166.693.460.644,- nilainya lebih kecil bila dibandingkan dengan nilai NPV yang dihitung berdasarkan versi syariah, baik dengan menggunakan nisbah bagi hasil berbasis penjualan yaitu NPV sebesar Rp 172.235.672.879,-- maupun nisbah bagi hasil berbasis keuntungan atau laba dengan NPV Rp 172.802.221.667,-.
2. Nilai hasil yang didapat oleh bank untuk masing-masing perhitungan yaitu Rp 62.706.528.253,- untuk perhitungan versi konvensional yang menggunakan tingkat suku bunga tetap $11 \%$, sedangkan perhitungan versi syariah yang menggunakan nisbah bagi hasil penjualan adalah $\mathrm{Rp}$ 40.620.930.557,- dan untuk perhitungan versi syariah yang menggunakan nisbah bagi hasil laba bersih adalah Rp 46.259.402.527,--

3. Nilai hasil yang didapat oleh bank dari perhitungan versi konvensional sebesar Rp 62.706.528.253,-- merupakan nilai terbesar yang diperoleh pihak bank. Nilai tersebut berasal dari pembayaran pokok dan bunga tetap pinjaman, sehingga dalam perhitungan ini pihak nasabah sedikit dirugikan karena harus membayar biaya lebih besar dibanding jika nasabah melakukan kerjasama pembiayaan menggunakan perhitungan versi syariah dengan nisbah bagi hasil.

4. Waktu mulai pembayaran angsuran pokok pembiayaan dan bagi hasil; untuk versi konvensional pembayaran angsuran Pertama mulai dibayar atau dihitung pada tahun ke-2 setelah pembiayaan dengan tingkat suku bunga tetap $11 \%$. Sedangkan versi syariah pembayaran angsuran pokok dan bagi hasil dilakukan setelah proyek menghasilkan dan dilakukan pada tahun ke-4 dan ke-5 pada saat kondisi tanaman sudah mulai menghasilkan.

5. Dasar perhitungan untuk versi konvensional yang menggunakan 
tingkat suku bunga tetap $11 \%$ berasal dari laporan keuangan neraca, sedangkan untuk versi syariah berasal dari laporan keuangan laba rugi atau laporan cash flow.

Berbeda dengan tingkat suku bunga bank yang nilai prosentasenya tetap dan pasti, untuk nisbah bagi hasil nilainya tidak tetap dan baru dibagi jika usaha sudah menghasilkan atau ada keuntungan. Jika kondisi perusahaan dalam keadaan rugi, maka kemungkinan tidak ada bagi hasil antar pihak yang bekerjasama, tetapi hal itu tergantung pada akad perjanjian kerjasamanya. Intinya prinsip kerjasama secara syariah lebih adil dibanding secara konvensional, karena resiko ditanggung bersama-sama oleh para pihak yang bekerjasama.

Berdasarkan hasil perhitungan persamaan peramalan $\mathrm{Y}=\mathrm{a}+\mathrm{bx}$, diketahui bahwa nilai b (koefisien regresi) untuk versi konvensional secara umum lebih kecil dibanding nilai $b$ (koefisien regresi) versi syariah. Hasil persamaan $\mathrm{Y}=\mathrm{a}+\mathrm{bx}$ disajikan pada tabel 25. Dengan nilai b yang lebih besar, maka dapat disimpulkan bahwa perhitungan kelayakan versi syariah lebih baik dibanding versi konvensional.

\section{KESIMPULAN DAN SARAN}

Hasil analisis kelayakan finansial versi syariah pada proyek investasi perkebunan kelapa sawit PT.X adalah layak untuk dibiayai oleh bank. Berdasarkan hasil perhitungan analisa kelayakan finansial baik versi konvensional maupun versi syariah, dapat disimpulkan bahwa proyek investasi perkebunan kelapa sawit PT.X seluas 2.000 Ha adalah layak untuk dibiayai oleh pihak bank. Dan secara hasil perhitungan analisa kelayakan finansial versi syariah lebih dari baik dari perhitungan versi konvensional.

Penelitian ini hanya melakukan analisa yang ditekankan pada kelayakan aspek finansial, sedangkan pada aspekaspek lain non finansial diasumsikan layak. Sehingga untuk mengetahui secara menyeluruh dan mendalam mengenai profil resiko dan kelayakan investasi perkebunan kelapa sawit perlu dilakukan analisa lanjutan atas semua aspek yang tidak dianalisa secara mendalam. Perlunya untuk melakukan kajian secara menyeluruh terhadap berbagai rumus perhitungan ekonomi Islam atau ekonomi syariah yang bebas instrumen suku bunga bank.

\section{DAFTAR PUSTAKA}

Antonio, M.Syafi'i. Bank Syariah Dari Teori Ke Praktek, PT. Gema Insani. Jakarta. 2001.

Fatah, N. Capital Budgeting \& Teori Portofolio. Edisi Pertama. Penerbit Andi offset.Yogyakarta. 1988

Gittinger, J Price. Analisa Ekonomi ProyekProyek Pertanian. UI Press. Jakarta. 1986.

Iska, Syukri. Sistem Perbankan Syariah Di Indonesia. Fajar Media Press. Yogyakarta. 2012. 
Karim, Adiwarman A. Bank Islam: Analisis

Fiqih dan Keuangan. Edisi keempat. PT. Raja Grafindo Persada, Jakarta. 2011.

Kasmir. Bank Dan Lembaga Keuangan Lainnya. PT. Raja Grafindo Persada, Jakarta. 2005.

Kasmir dan Jakfar. Studi Kelayakan Bisnis. Kencana Prenada Media Grup. Jakarta. 2003.

Koutsoyiannis, A. Theory of Econometrics.

Second Edition. The United

Kingdom by The Macmillan

Press Ltd. New York. 1977.

Muhammad. Manajemen Pembiayaan Bank

Syariah. UPP AMP YKPN. Yogyakarta. 2005.

Pahan, I. Kelapa Sawit : Manajemen Agribisnis dari Hulu hingga
Hilir. Cetakan kesebelas. PT. Penebar Swadaya. Jakarta. 2006.

Rivai, Veithzal, Amiur Nuruddin dan Faisar Ananda Arfa. Islamic Business and Economic Ethics. PT. Bumi Aksara, Jakarta. 2012.

Rivai, Veithzal dan Andria Permata Veithzal. Islamic Financial Management. PT. Raja Grafindo Persada, Jakarta. 2008.

Soeharto, I. Manajemen Proyek: Dari Konseptual Sampai Operasional. Cetakan Pertama. Penerbit Erlangga. Jakarta. 1995.

Undang-Undang Republik Indonesia Nomor 7 Tahun 1992 Tentang Perbankan.

Undang-Undang Republik Indonesia Nomor 21 Tahun 2008 Tentang Perbankan Syariah.

* Alumni Program Magister Agribisnis UIN Jakarta, ** Dosen Program Magister Agribisnis UIN Jakarta 